\section{BIBLIOGRAFIA BÁSICA DE LITERATURA GREGA}

\section{ADRIANE DA SILVA DUARTE Departamento de Letras Clássicas e Vernáculas Faculdade de Filosofia, Letras e Ciências Humanas Universidade de São Paulo}

Integrando a série Instrumentos de Pesquisa (Strumenti di Studio), voltada para a publicação de guias bibliográficos, a editora Garzanti dedicou um volume a Literatura Grega: Letterature Greca Antica, Bizantina e Neoellenica (Milano, 1989). Contraposto a obras de maior vulto, como L'Année Philologique, que têm a ambição de registrar toda a bibliografia no âmbito dos estudos clássicos, esse livro assume proporções mais modestas, limitando tanto a área de abrangência quanto o número de títulos arrolados. Mas justamente aí reside seu grande atrativo. Sua dimensāo e preço (28.000 liras) colocam-no na estante do pesquisador, onde estará à mão para quaisquer consultas, facilitando a primeira etapa de um trabalho.

Foi basicamente isso que o organizador, Marco Fantuzzi, tinha em mente ao reelaborar o material anteriormente publicado volume XII da Enciclopedia Europea. Seu objetivo era catalogar obras consagradas e, ao mesmo tempo, que fossem acessíveis aos estudiosos. $\mathrm{E}$ claro que ele pensava nas livrarias e bibliotecas européias, mas mesmo assim a adoção desse critério já nos protege um pouco da frustração, conhecida de qualquer pesquisador do terceiro mundo, de ter a indicação de um texto magnífico mas impossível de se encontrar.

$O$ volume está restrito à literatura grega, o que significa que só serão incluídas referências bibliográficas sobre Platão quando versarem sobre o estilo dos diálogos, sobre Heródoto e Tucídides quando se detiverem na constituição. da prosa historiográfica e assim por diante. Embora contemple as literaturas bizantina e grega moderna, seu núcleo está na literatura antiga (mais de trezentas das quatrocentos e setenta páginas), cuja abrangência vai da épica arcaica até a literatura greco-romana.

Esse vasto material foi organizado ora por gênero literário (épica, lírica do sec. VII a V a.C., teatro clássico, etc.), ora por período histórico (literatura helenística, greco-romana, bizantina, moderna). Cada um desses capítulos se subdivide na abordagem de temas específicos, autores e obras determinados. Assim o capítulo sobre o teatro compreende as seguintes partes: as origens, o drama grego clássico: estrutura e conteúdo, a tragédia ática, Esquilo, Sófocles, Eurípides, a comédia antiga, Aristófanes, a crise do teatro clássico e a comédia média. Para os dramaturgos, após a bibliografia geral, seguem-se as indicaçōes específicas para cada uma das obras.

Além dos capítulos mencionados, há um dedicado às obras gerais, ou seja, às ferramentas básicas do pesquisador: dicionários, coleçōes de textos, gramáticas, histórias da literatura e da língua além de um catálogo das principais revistas especializadas, com o local de publicação, ano de fundação e, quando é o caso, período de circulação.

Sempre que possivel, as indicaçōes bibliográficas vêm acompanhadas de pequenos comentários sobre o autor ou a obra, detendo-se nas teses mais polêmicas e remetendo o consulente para textos afins. $O$ índice onomástico de autores antigos e modernos facilita enormemente a consulta, permitindo localizar as obras de determinado helenista, às vezes dispersas pelos vários capítulos do livro.

O volume é aberto com um ensaio de Bruno Gentile que visa situar o es- 
tado atual dos estudos filológicos. Para isso ele apresenta os principais helenistas desse século (Jaeger, Snell, Fraenkel, Parry, Havelock, Dodds, Vernant, entre outros) e discute as idéias que mais repercutiram, em especial as que dizem respeito à questão da oralidade e seu impacto na compreensão dos textos antigos.

O livro cumpre o papel a que se propōe: orientar a travessia da enorme bibliografia de estudos helenísticos, fornecendo a base para as pesquisas na área. Seu ponto forte é a mescla de obras consagradas, de leitura imprescindível ao classicista, e de artigos recentes (i.é, até 1988), publicados em revistas. Seu único defeito está no direcionamento aos leitores italianos, o que faz com que as obras traduzidas para o italiano sejam citadas nas ediçōes locais, muitas vezes sem que haja a menção do título original. De qualquer forma, é útil.

A editora também pretende publicar volumes dedicados à filosofia e à arqueologia e arte antiga. 